\title{
The Effects of Secondhand Smoke Exposure on Serum Immunoglobulin E Levels among Children of Elementary School
}

\author{
Asti Widuri ${ }^{1 *}, \mathrm{~K}$ Triwulandari ${ }^{2}$ \\ ${ }^{1}$ Departement of Ear, Nose, and Throat Diseases, Faculty of Medicine and Health Sciences, Universitas Muhammadiyah \\ Yogyakarta, Bantul, Indonesia; ${ }^{2}$ Departement of Parasitology, Faculty of Medicine and Health Sciences, Universitas \\ Muhammadiyah Yogyakarta, Bantul, Indonesia
}

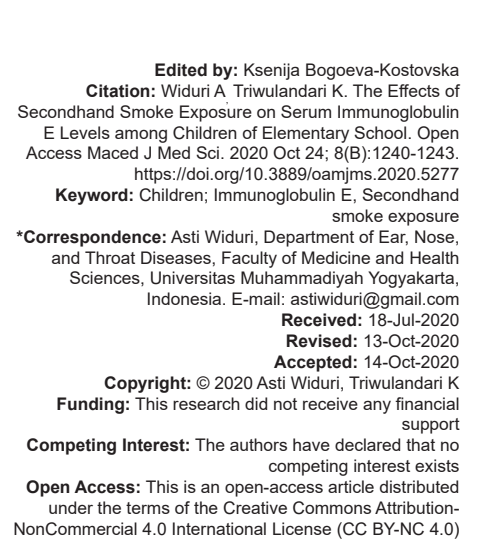

Introduction

Smoking has become a part of the lifestyle. Tobacco smoke exposure remains common and has been linked with an increased risk of multiple upper respiratory diseases, which causes severe conditions of various respiratory tract disorders and increases the dose of medicine therapy [1], [2]. Smoking activity not only bad for smokers but also has an impact for secondhand smoke. Significant impacts have been identified between tobacco smoke exposure and chronic sinusitis [3], asthma [4], allergic dermatitis, food allergy, and allergic rhinitis [5], [6].

Tobacco smoke contains irritants particle, such as sulfur dioxide, nitrogen that can affect the respiratory tracts and increase the activity of Th2 and immunoglobulin E ( $\operatorname{lgE}$ ) production. The high production of IgE caused by various mechanisms and local inflammation in the respiratory tract by smoke exposure. Therefore, frequents of smoke exposure, especially in the contact between tissues and allergen, could impact stimulating an immune system [7].

$\lg \mathrm{E}$ is a mediator with a quick type of hypersensitivity, including asthma, allergic rhinitis, atopic dermatitis, and urticaria. The high production of
IgE stimulated the cell membrane with the interaction between allergens that can produce specific lgE, mast cells, or basophils [8], [9]. The potential factors of high IgE production are allergens and environmental factors, including smoke exposure. On the other hand, the disrupted epithelial junctions can enhance airway inflammation and facilitate the release of allergen granules [8]. This study aims to determine the association between environmental secondhand smoke exposure and total IgE levels in serum among children of elementary school.

\section{Methods}

The research design in this study was observational research with a cross-sectional approach to evaluate the effect of tobacco secondhand smoke exposure on serum IgE level among children of elementary school. The smoke exposure was classified into two categories rarely and often that collected by secondhand exposure questionnaires. We also collected the ISAAC questionnaires focusing on symptoms 
of asthma, rhinitis, and eczema. The total IgE level examined from blood samples using the enzyme-linked immunosorbent assay (ELISA) method (ELISA kit for Human IgE total: Diagnostic Automation, Inc., Catalog No.: 1801Z). The resulted of IgE level divided into two categories are "higher than standard" and "normal" category. The value of the IgE level was categorized as "higher than standard" if the total IgE concentration was $\geq 100 \mathrm{lU} / \mathrm{mL}$. Meanwhile, it was classified as "normal" if the total $\mathrm{lgE}$ concentration was $<100 \mathrm{IU} / \mathrm{mL}$.

\section{Subjects}

According to sample size formulation by Lameshow and David, the researchers found the number of minimal sample size was 77 with consecutive sampling [10]. The inclusion criteria for this study were children who were 10-12 years old that already had informed consent from parents and free from helminth infection with feces examination by Kato method. Meanwhile, the exclusion criteria are children that have a history of severe allergies/ anaphylaxis, consumed anti-allergic drugs. This research has received ethical clearance from the Faculty of Medicine and Health Sciences Universitas Muhammadiyah Yogyakarta with number 239/ EP-FIKI-UMY/IV/2017.

\section{Statistical analysis}

The results in this study were managed electronically using SPSS software (Statistical Product for the Social Science) ${ }^{\odot}$ version 23.0. The statistical analysis used Chi-square statistical test to identify the relationship between tobacco smoke exposure and IgE levels.

\section{Results}

\section{Subject characteristics}

The study was conducted on 86 students of $6^{\text {th }}$ grade at Sukonandi Muhammadiyah Elementary School in Yogyakarta, Indonesia. The male students were $39(45.3 \%)$ and the female student was 47 students (45.7\%). Based on age, 10-year-old respondents were 8 students $(9.3 \%)$, 11-year-old respondents were 64 students $(74.4 \%)$, and 12-year-old respondents were 14 students (16.3\%) (Table 1).

The $\lg E$ levels examination result showed two categorized in the normal IgE levels were 37 students $(43.1 \%)$ and higher than the standard level of IgE were 49 students $(56.9 \%)$. On the $\lg E$ examination, the mean total IgE level in the serum of all students was $508.2 \mathrm{IU} / \mathrm{mL}$. The classification of $\mathrm{lgE}$ levels is shown in Figure 1.

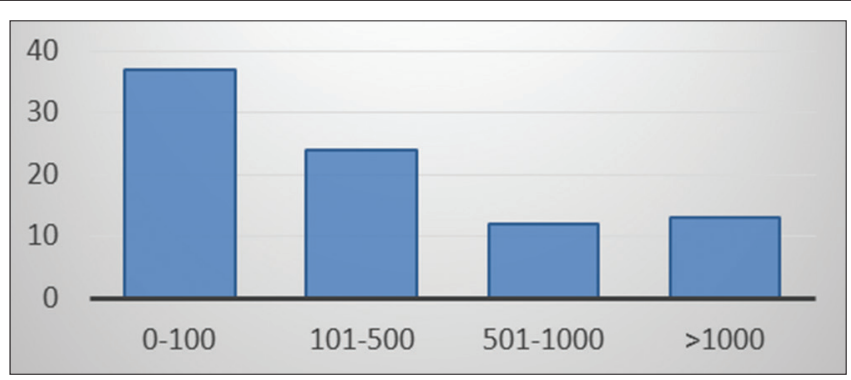

Figure 1: The result of IgE examination (IU/mL)

All children were reported that they obtained secondhand smoke exposure. The highest exposure to secondhand smoke was in public places. The association between exposure and IgE levels was shown in Table 2.

Table 1: Subjects' characteristics

\begin{tabular}{lll}
\hline Characteristic & $\mathrm{n}$ & Percentage \\
\hline Gender & 39 & \\
$\quad$ Male & 47 & 45.3 \\
$\quad$ Female & & 45.7 \\
Age & 8 & \\
10 years & 64 & 9.3 \\
11 years & 14 & 74.4 \\
12 years & & 16.3 \\
Immunoglobulin E level & 37 & 43.1 \\
$\quad$ Normal & 49 & 56.9 \\
$\quad$ Higher than standard & & \\
Secondhand smoke exposure & 37 & 43.1 \\
$\quad$ Rarely & 49 & 56.9 \\
$\quad$ Often & & \\
Place exposure & 40 & 46.5 \\
$\quad$ Home & 46 & 53.5 \\
$\quad$ Public & & \\
Rhinitis & 72 & 83.7 \\
$\quad$ Yes & 14 & 16.3 \\
$\quad$ No & & 25.6 \\
Asthma & 22 & 74.4 \\
$\quad$ Yes & 64 & \\
$\quad$ No & &
\end{tabular}

According to ISAAC questionnaires, the researcher identified the allergic disease symptoms of asthma and allergic rhinitis that influenced the lgE level with Chi-square. Based on the report, there were no statistically significant associations showed in Tables 3 and 4.

Table 2: The relationship between smoke exposure and immunoglobulin E serum

\begin{tabular}{llll}
\hline Parameter & $\begin{array}{l}\text { Immunoglobulin } \\
\text { E normal }\end{array}$ & $\begin{array}{l}\text { Immunoglobulin E higher } \\
\text { than standard }\end{array}$ & P-value \\
\hline SHS & & & \\
Rarely & 15 & 22 & 0.501 \\
Often & 22 & 27 & $\mathrm{Cl} 0.352-1.987$ \\
& & & OR 0.837 \\
\hline
\end{tabular}

\section{Discussion}

In this study was participated by 86 students. All students were exposed to secondhand smoke caused by public smokers and family smokers. In the family area, the research by Warren et al. [11] show the data about a variety of secondhand smoke exposure children in their homes varies from $27.6 \%$ in Africa, $34.3 \%$ in Southeast Asia, 50.6\% in Western Pacific, and up to $77.8 \%$ in Europe. 
Table 3: The relationship between allergic rhinitis history and IgE serum

\begin{tabular}{llll}
\hline Parameter & IgE normal & IgE higher than standard & p-value \\
\hline Allergic rhinitis & 6 & & \\
No & 6 & 8 & 0.055 \\
Yes & 31 & 49 & Cl 0.862-24.001 \\
& & & OR 4.548 \\
\hline IgE: Immunoglobulin E. & &
\end{tabular}

Children are the most susceptible population on the harmful effects of tobacco smoke. Although there were many evidences showing that tobacco smoke exposure is detrimental to children's health. Besides that, the impact of tobacco smoke exposure on the regulation of $\mathrm{IgE}$ that mediated by immune responses to specific allergens has not been well documented [12].

Table 4: The relationship between asthma history and IgE serum

\begin{tabular}{llll}
\hline Parameter & IgE normal & Higher than standard & p-value \\
\hline Asthma & & & \\
No & 30 & 34 & 0.291 \\
Yes & 7 & 15 & Cl 0.680-5.258 \\
& & & OR 1.891 \\
\hline IgE- Immunoglobulin E & &
\end{tabular}

The different explanation above, in this study, showed that the highest exposure to secondhand public places was $53.5 \%$. In line with the research in Korea conducted by Hwang et al. conclude that exposure to secondhand smoke in public places is higher than at home. Although smoking policies decreased in smoke tobacco exposure, children were exposed significantly not only in their homes but also in schools, restaurants, child-care house facility, cars, buses, and other public places [13].

This study showed that children with total serum higher than the standard of IgE levels were $56.9 \%$. The high standard level in line with research by Se-Ryun Kwon et al. showed that a high prevalence of allergic rhinitis, asthma, and atopic dermatitis in subjects exposed to passive smoking, compared to subjects not exposed to passive smoking. However, the difference was significant only for atopic dermatitis [9].

The secondhand tobacco smoke exposure association with IgE levels was not statistically significant $(p=0.501)$. It is similar to the study in Taiwan showed that there was no effect of tobacco smoke exposure with IgE levels [12]. In the Shargorodsky study, there was no influence between tobacco smoke exposure and IgE levels. Moreover, he revealed that exposure to contradictory tobacco smoke decreased IgE levels [1].

The other literature concluded that in allergic conjunctivitis cases, individuals with exposure to pet(s) and smoke at home were more likely to have high IgE levels compared to those who were not exposed [14]. Moreover, hereditary and lifestyle factors, such as farming environment, smoking, family members, body weight, or frequency of colds, significantly influenced the development of allergen-specific lgE in adolescents [15], [16].

This study invents the children with asthma and rhinitis history had higher than the standard level of IgE serum but not statistically significant $(p=0.055$, $p=0.219)$. It is different from the study by Froidure et al. [17] that showed an epidemiological association between $\operatorname{lgE}$ production and asthma. It is caused by allergen-specific IgE as mediate asthmatic responses in allergic individuals. Furthermore, the relationship between IgE responses and clinical expression of asthma integrated several co-factors influencing airway reactivity and asthma persistency.

\section{Conclusion}

Children with secondhand smoke exposure, asthma history, and rhinitis allergy showed higher than standard level lgE. However, it was not statistically significant.

\section{References}

1. Shargorodsky J, Garcia-Esquinas E, Galán I, Navas-Acien A Lin SY. Allergic sensitization, rhinitis and tobacco smoke exposure in US adults. PLoS One. 2015;10(7):e0131957. https://doi.org/10.1371/journal.pone.0131957

PMid:26172447

2. Goseva Z, Gjorcev A, Kaeva BJ, Janeva EJ, Angelovska I. Analysis of plasma concentrations of theophylline in smoking and nonsmoking patients with asthma. OA Maced J Med Sci. 2015;3(4):672-5. https://doi.org/10.3889/oamjms.2015.117 PMid:27275306

3. Reh DD, Higgins TS, Smith TL. Impact of tobacco smoke on chronic rhinosinusitis: A review of the literature. Int Forum Allergy Rhinol. 2012;2(5):362-9. https://doi.org/10.1002/alr.21054 PMid:22696460

4. Quinto KB, Kit BK, Lukacs SL, Akinbami LJ. Environmenta tobacco smoke exposure in children aged 3-19 years with and without asthma in the United States, 1999-2010. NCHS Data Brief 2013;126:1-8.

PMid:24152420

5. Cheraghi M, Salvi S. Environmental tobacco smoke (ETS) and respiratory health in children. Eur J Pediatr. 2009;168(8):897905. https://doi.org/10.1007/s00431-009-0967-3

PMid:19301035

6. Saulyte J, Regueira C, Montes-Martinez A, Khudyakov P, Takkouche B. Active or passive exposure to tobacco smoking and allergic rhinitis, allergic dermatitis, and food allergy in adults and children: A systematic review and meta-analysis. PLoS Med. 2014;11(3):e1001611. https://doi.org/10.1371/journal. pmed.1001939

PMid:24618794

7. Wells EM, Bonfield TL, Dearborn DG, Jackson LW. The relationship of blood lead with immunoglobulin $E$, eosinophils, and asthma among children: NHANES 2005-2006. Int J Hyg Environ Health. 2014;217(2-3):196-204. https://doi. org/10.1016/j.ijheh.2013.04.010 PMid:23726529

8. Kim YS, Kim HY, Ahn HS, Sohn TS, Song JY, Lee YB, et al. The association between tobacco smoke and serum immunoglobulin 
E levels in Korean adults. Intern Med. 2017;6(19):2571-7. https://doi.org/10.2169/internalmedicine.8737-16

PMid:28883244

9. Se-Ryun Kwon, Park D, Shim SJ, Heo JH, Kwon SM, Seo DY. Association between passive smoking and serum total $\mathrm{lgE}$, allergic diseases in Korean nonsmoking adults: Korean national health and nutrition examination survey 2010 . Korean J Fam Pract. 2016;6(6):688-94. https://doi.org/10.21215/ kjfp.2016.6.6.688

10. Lameshow S, David WH. Besar Sample Dalam Penelitian Kesehatan. Yogyakarta: Gadjah Mada University Press; 1997.

11. Warren CW, Jones NR, Peruga A, Chauvin J, Baptiste JP, Costa de Silva V, et al. Global youth tobacco surveillance, 2000-2007. MMWR Surveill Summ. 2008;57:1-28.

PMid:18219269

12. Thacher JD, Gruzieva O, Pershagen G, Neuman $\AA$, van Hage $M$, Wickman $\mathrm{M}$, et al. Parental smoking and development of allergic sensitization from birth to adolescence. Allergy. 2016;71(2):239-48. https://doi.org/10.1111/all.12792 PMid:26475651

13. Hwang $\mathrm{SH}$, Hwang JH, Moon JS, Lee $\mathrm{DH}$. Environmental tobacco smoke and children's health Korean J Pediatr. 2012;55(2):35-41. https://doi.org/10.3345/kjp.2012.55.2.35
PMid:22375147

14. Dermer H, Theotoka D, Lee CJ, Chhadva P, Hackam AS, Galor A, et al. Total tear IgE levels correlate with allergenic and irritating environmental exposures in individuals with dry eye. J Clin Med. 2019;8(10):1627. https://doi.org/10.3390/jcm8101627 PMid:31590324

15. Stemeseder T, Klinglmayr E, Moser S, Lang R, Himly M, Oostingh GJ, et al. Influence of intrinsic and lifestyle factors on the development of IgE sensitization. Int Arch Allergy Immunol. 2017;173(2):99-104. https://doi.org/10.1159/000475499 PMid:28654924

16. Hisinger-Mölkänen $H$, Piirilä $P$, Haahtela $T$, Sovijärvi $A$ Pallasaho P. Smoking, environmental tobacco smoke and occupational irritants increase the risk of chronic rhinitis. World Allergy Organ J. 2018;11(1):6. https://doi.org/10.1186/ s40413-018-0184-5

PMid:29568342

17. Froidure A, Mouthuy $J$, Durham $S R$, Chanez $P$, Sibille Y, Pilette C. Asthma phenotypes and IgE responses. Eur Respir J. 2016;47(1):304-19. https://doi. org/10.1183/13993003.01824-2014

PMid:26677936 